\title{
Effects of Dexamethasone on the Morphometry and Biometry of Immune Organs of Broiler Chicken
}

\author{
Efectos de la Dexametasona en la Morfometría y Biometría \\ de los Órganos Inmunes del Pollo de Engorde
}

Nasrin Sultana'; Tanjina Amin'; Marzia Afrose²; Sharmin Aqter Rony ${ }^{3}$ \& Kazi Rafiq ${ }^{4}$

SULTANA, N.; AMIN, T.; AFROSE, M.; AQTER, R. S. \& RAFIQ, K. Effects of dexamethasone on the morphometry and biometry of immune organs of broiler chicken. Int. J. Morphol., 38(4):1032-1038, 2020.

SUMMARY: The study was conducted to examine the histological changes i.e. morphology and biometry of immune organs (thymus, spleen and bursa cloacalis or «Fabricius») of broilers in response to dietary dexamethasone (DEX). The day old chicks were obtained from the commercial hatchery and randomly divided into two groups i.e. control and experimental or treated group. The control group was reared on commercial broiler ration and the experimental group $(n=25)$ was maintained on commercial broiler ration with corticosteroid (Dexamethasone-Decason, BP $0.5 \mathrm{mg}$, Opsonin @ $7 \mathrm{mg} / \mathrm{kg}$ feed). Samples (bursa cloacalis, spleen, and thymus) were collected from the ten control and ten experimental broilers at 14 and 28 days of experiment; then tissues were stained with Hematoxylin and Eosin. The biometric measurements of the samples were performed by the calibrated stage micrometer. Finally, the obtained data were analyzed using GraphPad Prism 8 software. In DEX treated group, the morphology of thymus, spleen and bursa cloacalis did not show any abnormal alterations. But their development rate was slower on visual inspection in DEX treated group. The length and width of bursal follicle of bursa cloacalis, thymic lobule of thymus and white pulp of spleen were statistically consisted but numerically decreased in DEX treated group than the control. The present findings suggested that DEX does not affect the histological architectures of immune organs except causing developmental arrest. Numerical decrease in the biometry of immune organs indicates that DEX causes apoptosis of immune cells in lymphoid organs of broiler.

KEY WORDS: Broiler; Dexamethasone; Immune organs.

\section{INTRODUCTION}

Poultry industry is one of the leading fast- growing agricultural sub-sectors throughout the world. According to FAO statistical database 2016, global population of poultry is around 23 billion resulting 3 birds per person. Annual per capita consumption of poultry meat has risen from 2.88 to $14.13 \mathrm{~kg}$. Overall production has drastically been elevated in developing countries, more specifically in East and South East Asia countries, with a growth rate of $7.4 \%$ per annum (Mottet \& Tempio, 2017). In poultry industry, cheap and quality cheap and quality feed formulation constitutes the major input that determines the most profit margins. Without suitable feed, host genetic potential will not be triggered fully even of most suitable broiler strain (Kalia et al., 2017). Different kinds of growth promoters (GPs) are frequently supplemented in broiler feed in order to maximize genetic potentiality, to enhance feed conversion ratio (FCR), greater livability and lowered mortality in birds (Dhama et al., 2014; Mostafa et al., 2016).

The broadspectrum effect of GPs on health and production performance has triggered the discovery and widespread use of large number of feed probiotics. Although GPs are non-nutirent and used in small amount in feed, they can maximize the utilization of feed-nutrients by improving gut health and immunity (Dhama et al.). Different types of antibiotics, vitamins, minerals and steroids are used as GPs to enhance growth of meat producing animals and birds. Steroids are especially used to increase the carcass weight in livestock legally or illegally (Serratosa et al., 2006; Yuan et al., 2008; Jeong et al., 2010). A good number of evidence

\footnotetext{
${ }^{1}$ Dept. of Anatomy and Histology, Bangladesh Agricultural University, Mymensingh, Bangladesh.

${ }^{2}$ Faculty of Life Science, Bangabandhu Sheikh Mujibur Rahman Science and Technology University, Gopalganj, Bangladesh.

${ }^{3}$ Dept. of Parasitology, Bangladesh Agricultural University, Mymensingh, Bangladesh.

${ }^{4}$ Dept. of Pharmacology, Bangladesh Agricultural University, Mymensingh, Bangladesh.
} 
suggested that the indiscriminate use of steroids, especially corticosteroids in developing countries like Bangladesh (Islam et al., 2013; Kamal et al., 2019).

Glucocorticoids (GCs) are steroid hormones including both natural and synthetic derivatives (Cantiello et al., 2009). More than 50 steroids have been isolated from the adrenal cortex. Only a few are primarily responsible for the effects that the adrenal cortex exerts in the body such as carbohydrate, protein and fat metabolism, increase gluconeogenesis, decrease peripheral utilization of glucose, antagonism to insulin, increased protein catabolism, reduced fat storage, anti-inflammatory effects including reduced circulatory lymphocytes, eosinophils and fixed lymphocytic tissues and reduction of degree of local inflammatory processes (Yuan et al.).

Dexamethasone (DEX) is a synthetic derivative of glucocorticoids, whose major therapeutic usage derives from their anti-inflammatory and immunosuppressant properties (Watteyn et al., 2013). Currently, stress is considered one of the major predisposing factors for poultry diseases in the poultry sectors. DEX is an immunosuppressant drug that is widely used to study some stressor effects in development and course of poultry diseases (Shini et al., 2010). Being close to endogenous corticosteroids, DEX was supposed to induce effects similar to elevated concentration of corticosterone and trigger stress-related signaling pathways (Calefi et al., 2016). The effect of DEX on lymphocytes from the spleen, mesenteric and popliteallymphnodes was less pronounced (Jeklova et al., 2008). In addition, DEX treatment yielded granulocytophilia and reduced mononuclear cells in human, lymphopenia and neutrophilia in rat, neutrophilia and eosinopenia associated with lymphopenia, monocytosis in cattle, neurtorphilia and lymphopenia in pigs as reviewed by Aengwanich (2007). Weight loss of immune organs (Vicuña et al., 2015) and depleted blood lymphocytes were also recorded in DEX treated broiler chicks (Aengwanich; Afrose et al., 2018). Besides liver enlargement, both weight and function of lymphoid organs including thymus, bursa of Fabricius and spleen were found to decline by corticosteroid treatment in birds (Mehaisen et al., 2017). Dietary application of DEX in broiler can easily be a feasible, controlled, and flexible tool in the search of host adaptation process to stressors. However, the relative proportion of change in the weight of immune organs from dietary DEX therapy is not wellinvestigated yet. Therefore, the present research aimed to analyze the effects of a dietary DEX on the immune organs (thymus, spleen and bursa of Fabricius) of broiler chickens.

\section{MATERIAL AND METHOD}

Ethical approval: The present study and all experimental procedures were approved and performed according to the guidlines for the care and use of animals as established by Animal welfare and Experimentation Ethics Committee, Bangladesh Agricultural University, Mymensingh [AWEEC/ BAU/2019(27)].

Experimental design: The day old chicks were obtained from commercial hatchery and randomly divided into two groups i.e. control and experimental or treated group. The control group $(n=25)$ was reared on commercial broiler ration and fresh drinking water (Fig. 1). The experimental group $(n=25)$ was maintained on commercial broiler type ration with corticosteroid (Dexamethasone, BP $0.5 \mathrm{mg}$, Opsonin Ltd@ $7 \mathrm{mg} / \mathrm{kg}$ feed) and fresh drinking water.

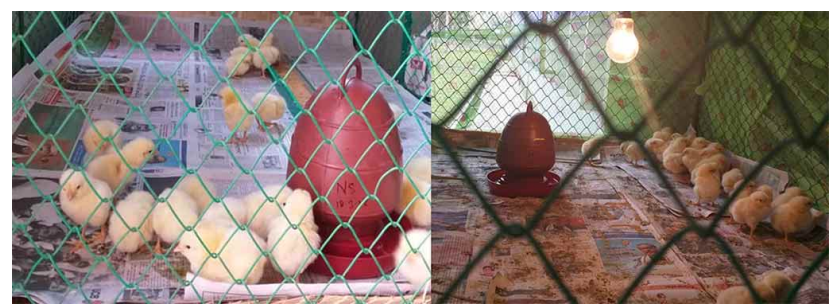

Fig. 1. Broiler rearing (Cobb 500 strain) at day 2 of experiment.

Sample collection: To examine the effects on immune organs (bursa cloacalis, spleen, and thymus), the samples were taken from ten control and ten experimental broilers at each of the sampling days at 14 and 28 days (Fig. 2). The tissue samples were collected by dissection immediately after slaughtering of the birds. After collecting, the tissue samples were preserved in $10 \%$ formalin. Then, the samples were kept for routine staining procedure.
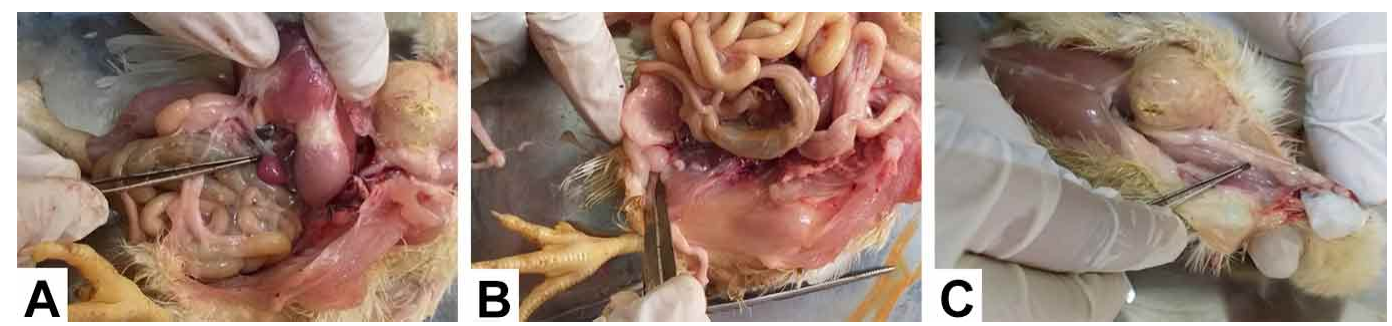

Fig. 2. Sample collection from broiler. (a) spleen, (b) Bursa cloacalis and (c) Thymus at day 14 of experiment. 
Processing of tissues for histological study: For histological studies, the fixed tissues were dehydrated in the series of ascending grade of alcohol followed by clearing in three changes in xylene. Then, the tissues were infiltrated with different graded of melted paraffin $\left(49^{\circ} \mathrm{C}, 55^{\circ} \mathrm{C}\right.$, and $58^{\circ} \mathrm{C}$ ) at 30 minutes interval. The tissues were then embedded in paraffin $\left(58{ }^{\circ} \mathrm{C}\right)$ and finally the sections were cut at $6 \mathrm{~m}$ thickness using sliding microtome (MIC 509, Euromex, Japan). After cutting, the sections were floated on luke-warm water in a floatation bath at $37{ }^{\circ} \mathrm{C}$ for stretching and then the sections were mounted on clean slides using an adhesive (egg albumins) and dried on a slide warmer at $37^{\circ} \mathrm{C}$. The sections were then stained using Mayer's Hematoxylin and Eosin (H \& E).

Morphometric study and biometric measurement: The histological structures of the lymphoid tissues were observed using light microscope under low $(\times 10)$ and high $(\times 40)$ magnifications. Photographs were taken from the selected specimens. Then the biometric measurements of different histological structures of the lymphoid tissues were performed using calibrated stage micrometer in $\mathrm{mm}$ (micrometer).Twenty sections (ten from control group and ten from treatment group) were morphometrically evaluated
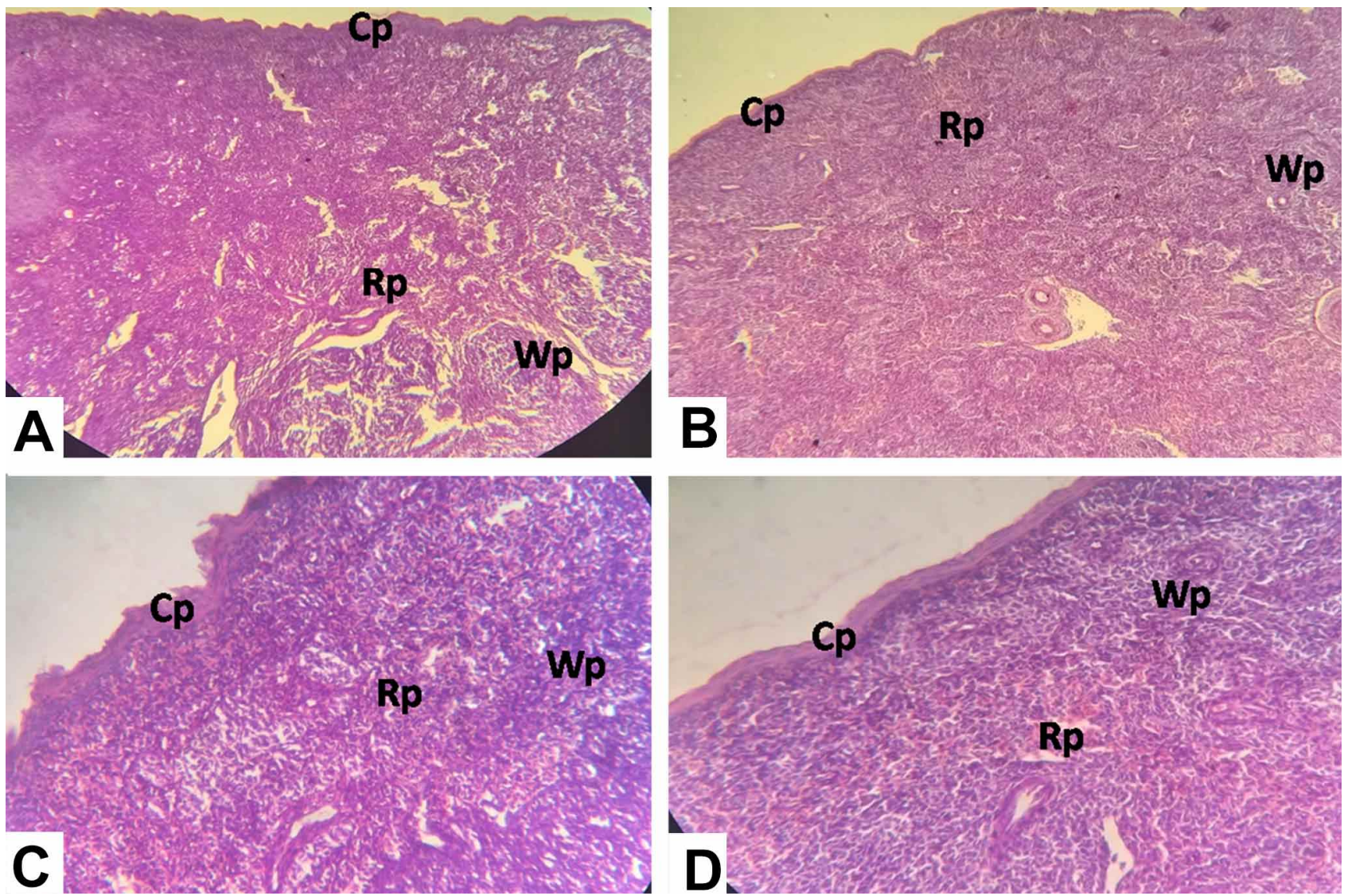

Fig. 3. Photomicrographs of spleen of control and experimental broiler stained with Hematoxylin-Eosin. (A) Histomorphological structures of spleen in control group. (B) Histological structures of spleen of broiler treated with dexamethasone. Cp: capsule; Wp: White pulp; Rp: Red pulp. 
lymphatic nodules. The red pulp of the spleen was composed of venous sinuses and anastomosing cord of reticular cells, macrophages, lymphocytes and blood cells. The morphology of the spleen did not show any abnormal alterations in the treatment group than in the control group (Fig. 3). Only the development of splenic pulps (visual inspection) was slower in the DEX treatment group as compared to the control group.

A numerical decrease is observed in the length $(123.37 \mathrm{~mm}$ in control group and 74.62 $\mathrm{mm}$ in treatment group whereas $231 \mathrm{~mm}$ in control group and $115.5 \mathrm{~mm}$ in treatment group at day 14 and 28 respectively) and width $(86.62 \mathrm{~mm}$ in control group and $76.12 \mathrm{~mm}$ in treatment group whereas $164 \mathrm{~mm}$ in control group and $126 \mathrm{~mm}$ in treatment group at day 14 and 28 respectively) of white pulp of spleen in DEX treated group as compared to the control group at day 14 and day 28 of experiment (Figs. 4 and 5).

Effects of DEX on thymic morphology and biometry: The control birds of the present experiment showed lobular nature of the thymus. The lobes of the thymus were surrounded by a capsule from it arise incomplete interlobular septa dividing the gland into lobules. Each lobule showed an outer deeply stained area, the cortex which was densely packed with lymphocytes and a central lightly stained area, the medulla with many epithelial cells predominated over the lymphocytes and the corticomedullary junction was clear. In both cortex and medulla, lymphocytes appeared as small rounded cells with large nucleus and dispersed chromatin whereas epithelial cells appeared with large pale nucleus. In DEX treated broiler, the cortex and the medulla did not show any abnormal morphological changes (Fig. 6).

The length (104.88 mm in control group and $76 \mathrm{~mm}$ in treatment group whereas $115.5 \mathrm{~mm}$ in control group and $84 \mathrm{~mm}$ in treatment group at day 14 and 28 respectively) and width (73.25 $\mathrm{mm}$ in control group and $78.62 \mathrm{~mm}$ in treatment group whereas $91.87 \mathrm{~mm}$ in control group and $81.12 \mathrm{~mm}$ in treatment group at day 14 and 28 respectively) of thymic follicles were numerically decreased in DEX treated group as compared to the control group at day 14 and day 28 of the experiment (Figs. 6 and 7).

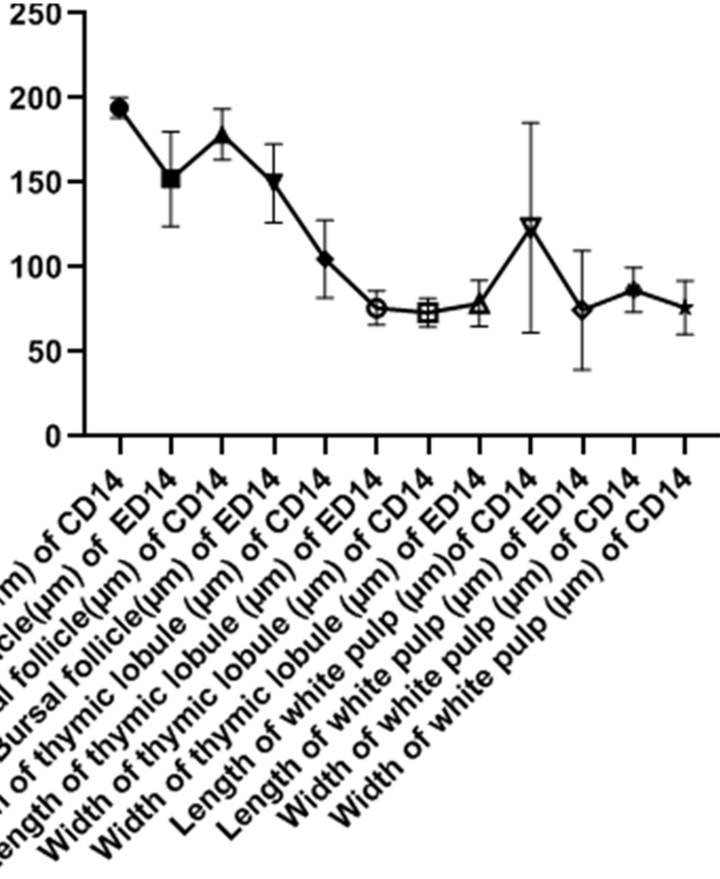

Fig. 4. Biometry of immune organs of control and experimental groups of broiler at day 14 of experiment.

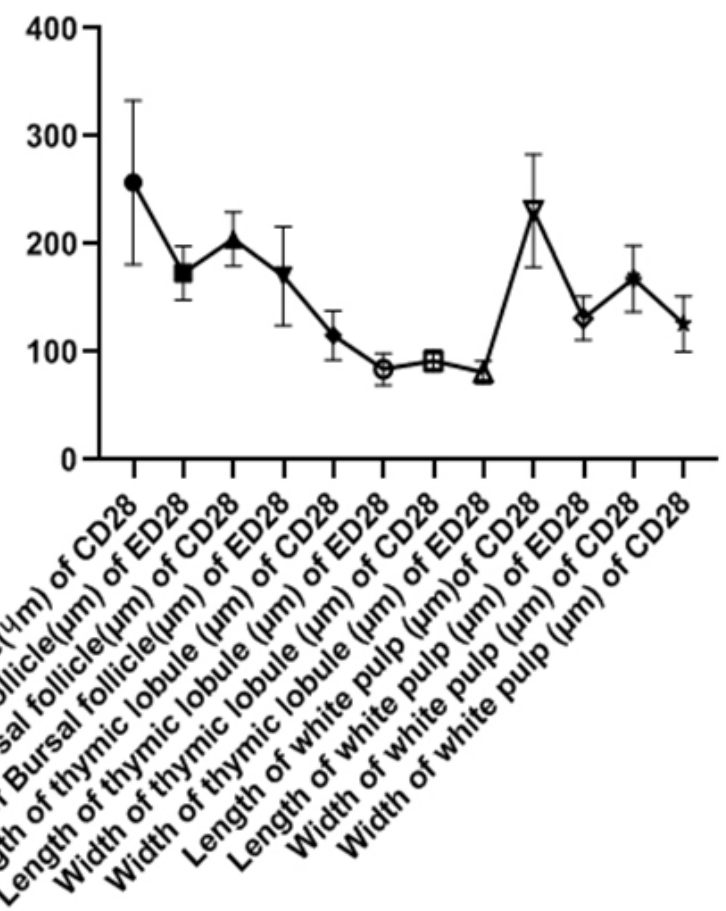

Fig. 5. Biometry of immune organs of control and experimental groups of broiler at day 28 of experiment. 

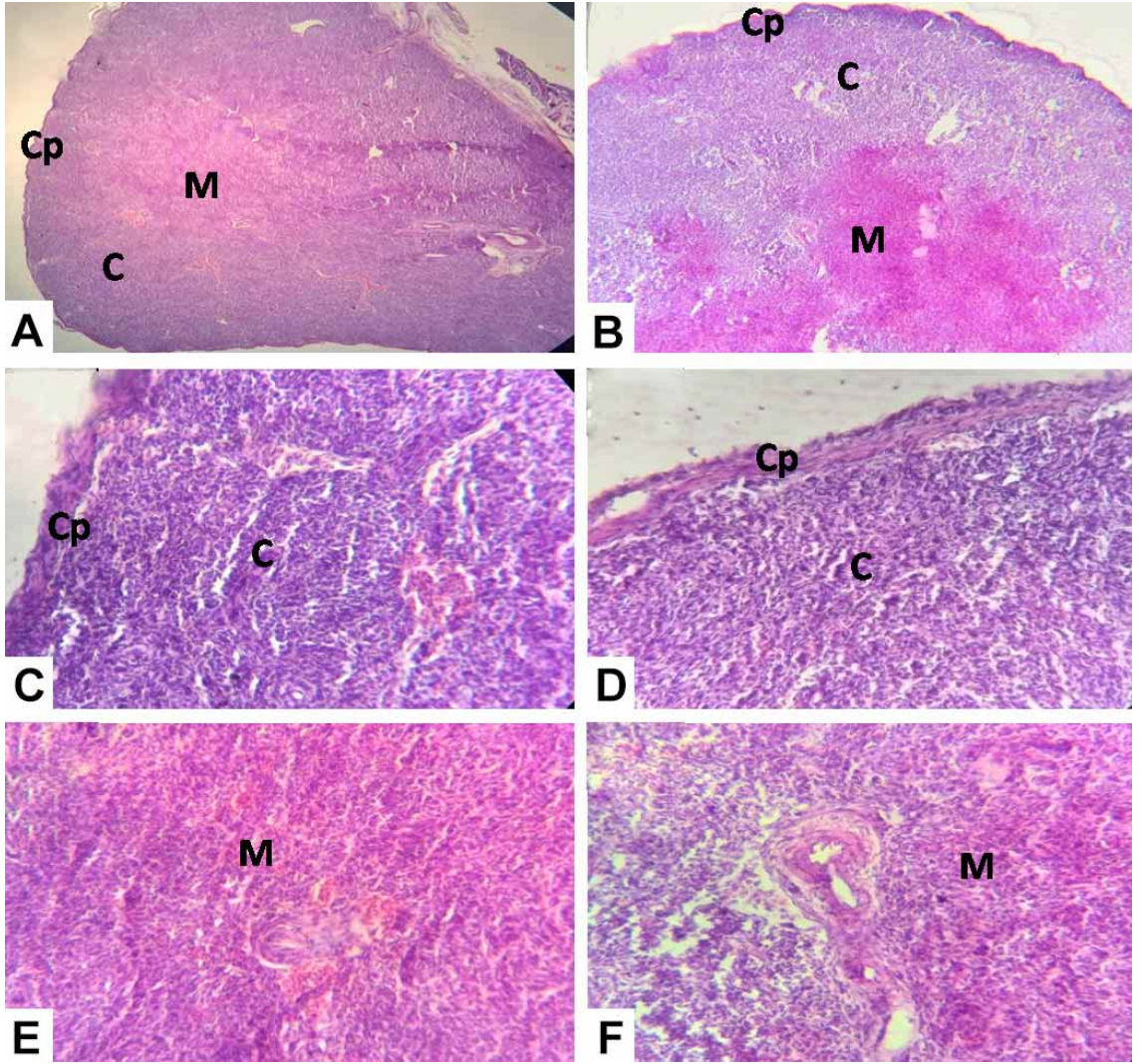

Fig. 6. Broiler Thymus Hematoxylin-Eosin stained. (A) Histological structures of Thymus control group; (B) Histological structures of Thymus of broiler treated with dexamethasone. Cp: Capsule; C: Cortex; M: Medulla.
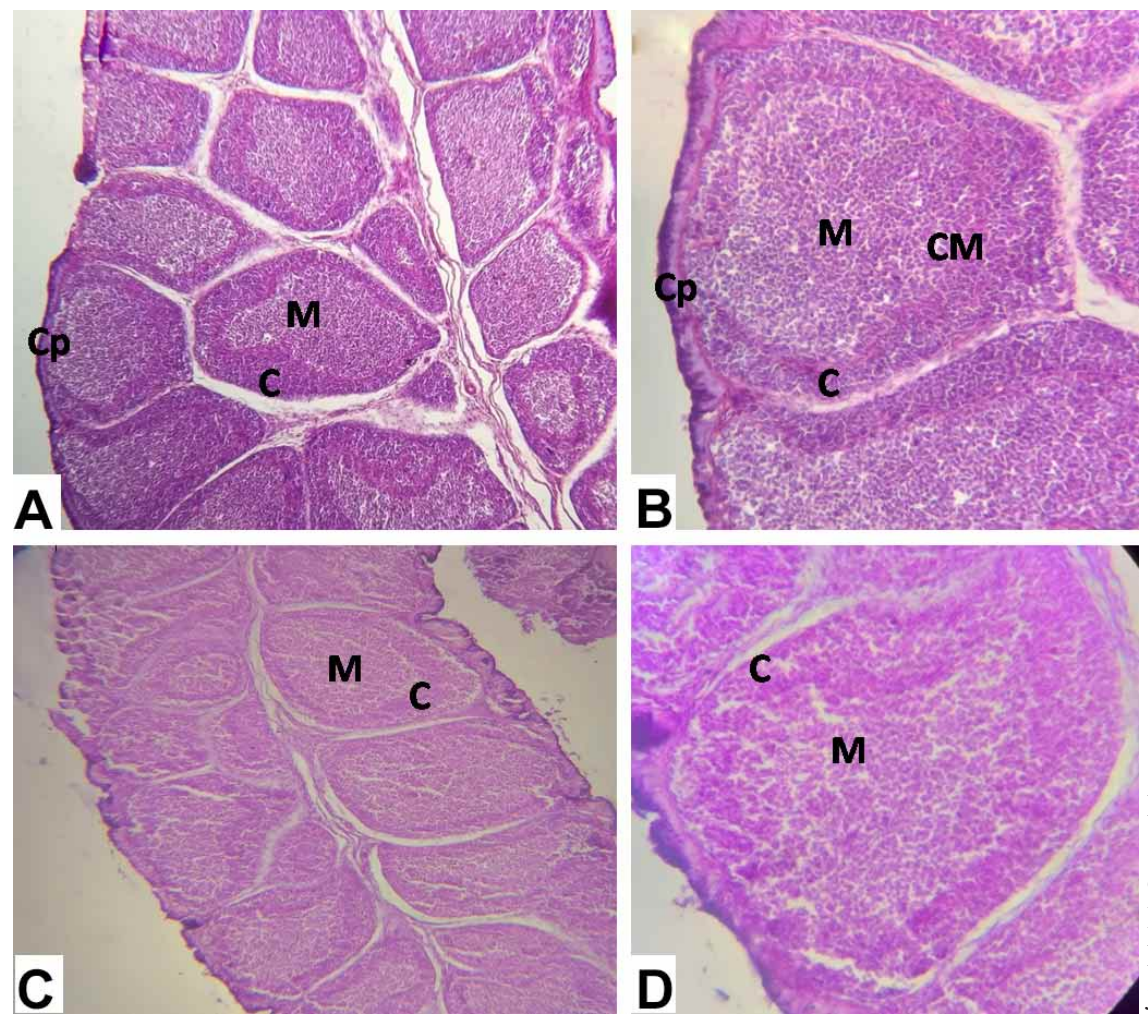

Effects of DEX on bursal morphology and biometry: In control group, the bursa cloacalis composed of numerous mucosal folds or plicae. The middle region of the fold was thicker than the base and apical portion. There were numerous follicles in the lamina propria of each fold. All the bursal follicles had clear margin and they were separated from the adjacent lymphoid tissue by connective tissue fibers, cells and intercellular space. Each bursal follicle was composed of a peripheral cortex and a central medulla. There is a capillary layer between the cortex and medulla. The darkly stained cortex was filled with many closely packed lymphocytes whereas the pale stained medulla contained fewer cells of various sizes. In DEX treated group, all the morphological structures remained same. But the bursa cloacalis was characterized by poorly developed bursal follicles with less differentiation into cortex and medulla in treatment group as compared to the control group (Fig. 7).

The length (194.25 $\mathrm{mm}$ in control group and $152.12 \mathrm{~mm}$ in treatment group whereas $257.25 \mathrm{~mm}$ in control group and $173.25 \mathrm{~mm}$ in treatment group at day 14 and 28 respectively) and width (178.5 mm in control group and $149.62 \mathrm{~mm}$ in treatment group whereas $204.75 \mathrm{~mm}$ in control group and $170.62 \mathrm{~mm}$ in treatment group at day 14 and 28 respectively) of bursal follicle is statistically consistent but numerically decreased in DEX treated group as compared to control group at day 14 and day 28 of experiment (Figs. 6 and 7).

Fig. 7. Broiler Bursa Hematoxylin-Eosin stained. (A) Histological structures of Bursa, control group. (B) Histological structures of Bursa, treatment group. Cp: Capsule; F: Follicle; C: Cortex; CM: Cortico-medullary junction; M: Medulla. 


\section{DISCUSSION}

Effects of DEX on splenic morphology and biometry: The present qualitative histomorphological analysis of spleen showed normal in appearance as previously reported in chicken by Akter et al. (2006). In the current research, DEX delayed the development of splenic pulps of spleen in broiler chicken. The length and width of splenic pulps were numerically decreased in DEX treated broiler chicken. These studies might be the reason for reducing relative weight of spleen in DEX treated chicken (Vicuña et al.). In chicken, the number of macrophages is also decreased by DEX treatment (Calefi et al.).

Effects of DEX on thymic morphology and biometry: Thymus is a primary lymphoid organ, composed of thymic follicles covered by a capsule. Each lobule composed of cortex, composed of immature T cells and medulla, composed of mature T-cells (Sultana et al., 2011; Treesh et al., 2014). Morphometric analyses of thymuses in chicken revealed that the volumetric ratio of the cortex and medulla was approximately 3 to 2 (Bódi et al., 2015). It has been reported that DEX activates the signaling pathway of cell death or apoptosis in thymus of rat (Hussar et al., 2011). The present study revealed that there are no morphological differences in the thymic follicles of broiler chicken between the control and experimental groups. In rabbit, cortical lymphocytes are destroyed in the thymus and lymph nodes, leading to cortical atrophy in response to DEX treatment (Cannizzo et al., 2010). In the current research, biometric measurements were performed on individual thymic follicle instead of cortex and medulla. The biometric differences found in DEX treated group might be due to the activation of signaling pathway of cell death or apoptosis either in cortex or medulla in thymus of broiler chicken.

Effects of DEX on bursal morphology and biometry: In the present study, the bursal follicles were poorly developed with less differentiation of cortex and medulla of bursa cloacalis in DEX treated broiler. The DEX decrease the relative weight of bursa cloacalis in chicken (Vicuña $e t$ $a l$.), might be due the poor development of bursa cloacalis. The histomorphological structures of bursa cloacalis in both the control and DEX treatment groups remained normal in the current study as previously discussed in chicken and duck (Akter et al.; Sultana et al.). The length and width of bursal follicles are numerically decreased in DEX treated broiler chicken is in line with Higgins et al. (2002) who have detected a significant decrease in the number of proliferating lymphocytes in bursal tissues treated with DEX as compared to control tissue.
The histomorpholgical architectures of immune organs (thymus, spleen, and bursa cloacalis) did not show any abnormal alterations in both the control and DEX treated broiler chicken. But the development and maturation of the structures of immune organs were delayed by DEX. The biometry of immune organs was influenced by DEX in broiler chicken. The biometric differences obtained in the immune organs might be due the activation of cell death signalling pathway. This study laid the foundation for further immunohistochemical detection of cell death and plasma cells distribution in the immune organs of broiler chicken in response to DEX.

\section{ACKNOWLEDGEMENTS}

We appreciate the research assistance from the Department of Anatomy and Histology, Faculty of Veterinary Science, Bangladesh Agricultural University, Mymensingh. We acknowledge the technical support from the Department of Parasitology, faculty of veterinary science, Bangladesh Agricultural University, Mymensingh. Dr. Nasrin Sultana is received the research fund from the Ministry of Science and Technology (BS-379; GO-46), Bangladesh.

SULTANA, N.; AMIN, T.; AFROSE, M.; AQTER, R. S. \& RAFIQ, K. Efectos de la dexametasona en la morfometría y biometría de los órganos inmunes del pollo de engorde. Int. J. Morphol., 38(4):1032-1038, 2020.

RESUMEN: El estudio se realizó para examinar los cambios histológicos, es decir, la morfología y la biometría de los órganos inmunes (timo, bazo y bolsa cloacal) de pollos de engorde en respuesta a la dexametasona en la dieta (DEX). Los pollitos de un día se obtuvieron de un criadero comercial y se dividieron aleatoriamente en dos grupos, control y experimental. El grupo control se crió con una ración comercial de pollos de engorde y el grupo experimental $(\mathrm{n}=25)$ se mantuvo con una ración comercial de pollos de engorde con corticosteroides (DexamethasoneDecason, BP 0,5 mg, Opsonin @ $7 \mathrm{mg} / \mathrm{kg}$ ). Se recogieron muestras (bolsa cloacal, bazo y timo) de los diez pollos del grupo control y diez del grupo de engorde experimental, a los 14 y 28 días de experimento. Luego, los tejidos se tiñeron con hematoxilina y eosina. Las mediciones biométricas de las muestras fueron realizadas con un micrómetro calibrado. Finalmente, los datos obtenidos se analizaron utilizando el software GraphPad Prism 8. En el grupo tratado con DEX, la morfología del timo, el bazo y la bolsa cloacal no mostraron alteraciones anormales. Pero su tasa de desarrollo fue más lenta en la inspección visual en el grupo tratado con DEX. La longitud y el ancho del folículo bursal de la bolsa cloacal, el lóbulo tímico del timo y la pulpa blanca del bazo fueron estadísticamente consistentes, pero disminuyeron numéricamente en el grupo tratado con DEX en relación al control. Los hallazgos actuales sugirieron que DEX no afecta la arquitectura histológica 
de los órganos inmunes, excepto que causa una detención del desarrollo. La disminución numérica en la biometría de los órganos inmunes indica que DEX provoca apoptosis de las células inmunes en los órganos linfoides de los pollos de engorde.

\section{PALABRAS CLAVE: Pollos de engorde; Dexametasona; Órganos inmunes.}

\section{REFERENCES}

Aengwanich, W. Effects of dexamethasone on physiological changes and productive performance in broilers. Asian J. Anim. Vet. Adv., 2(3):15761, 2007.

Afrose, M.; Sultana, N. \& Islam, M. R. Physiological responses of corticosteroid, dexamethasone in broiler chicken. Int. J. Sci. Res., 7(12):1459-63, 2018

Akter, S.; Khan, M. Z. I.; Jahan, M. R.; Karim, M. R. \& Islam, M. R. Histomorphological study of the lymphoid tissues of broiler chickens. Bangladesh J. Vet. Med., 4(2):87-92, 2006.

Bódi, I.; Minkó, K.; Molnár, D.; Nagy, N. \& Oláh, I. A novel aspect of the structure of the avian thymic medulla. Cell Tissue Res., 359(2):489501, 2015.

Calefi, A. S.; Quinteiro-Filho, W. M.; Fukushima, A. R.; da Cruz, D. S. G.; de Siqueira, A.; Salvagni, F. A.; Namazu, L. B; Gomes, C. O. M. S.; Ferreira, A. J. P. \& Palermo Neto, J. dexamethasone regulates macrophage and $\mathrm{Cd} 4+\mathrm{Cd} 25+$ cell numbers in the chicken spleen. Rev. Bras. Cienc. Avic., 18(1):93-100, 2016.

Cannizzo, F. T.; Spada, F.; Benevelli, R.; Nebbia, C.; Giorgi, P.; Brina, N.; Bollo, E. \& Biolatti, B. Thymus atrophy and regeneration following dexamethasone administration to beef cattle. Vet. Rec., 167(9):338-43, 2010.

Cantiello, M.; Giantin, M.; Carletti, M.; Lopparelli, R. M.; Capolongo, F.; Lasserre, F.; Bollo, E.; Nebbia, C.; Martin, P. G.; Pineau, T.; et al. Effects of dexamethasone, administered for growth promoting purposes, upon the hepatic cytochrome P450 3A expression in the veal calf. Biochem. Pharmacol., 77(3):451-63, 2009.

Dhama, K.; Tiwari, R.; Khan, R. U.; Chakraborty, S.; Gopi, M.; Karthik, K.; Saminathan, M.; Desingu, P. A. \& Sunkara, L. T. Growth promoters and novel feed additives improving poultry production and health, bioactive principles and beneficial applications: The trends and advances-A review. Int. J. Pharmacol., 10(3):129-59, 2014.

Higgins, S. E.; Berghman, L. R; Moore, R. W.; Caldwell, D. J.; Caldwell, D. Y.; Tizard, I. \& Hargis, B. M. In situ detection and quantification of bursa of fabricius cellular proliferation or apoptosis in normal or steroidtreated neonatal chicks. Poult. Sci., 81(8):1136-41, 2002.

Hussar, P.; Tokin, I.; Filimonova, G. \& Hussar, Ü. Dexamethasone-induced T-lymphocyte apoptosis in different lymphoid organs. Pap. Anthropol., 20:117-27, 2011.

Islam, M. H.; Hashem, M. A.; Hossain, M. M.; Islam, M. S.; Rana, M. S. \& Habibullah, M. Present status on the use of anabolic steroids and feed additives in small scale cattle fattening in Bangladesh. Progress. Agric., 23(1-2):1-13, 2013.

Jeklova, E.; Leva, L.; Jaglic, Z. \& Faldyna, M. Dexamethasone-induced immunosuppression: a rabbit model. Vet. Immunol. Immunopathol., 122(3-4):231-40, 2008.

Jeong, S. H.; Kang, D.; Lim, M. W.; Kang, C. S. \& Sung, H. J. Risk assessment of growth hormones and antimicrobial residues in meat. Toxicol. Res., 26(4):301-13, 2010.

Kalia, S.; K Bharti, V.; Gogoi, D.; Giri, A. \& Kumar, B. Studies on the growth performance of different broiler strains at high altitude and evaluation of probiotic effect on their survivability. Sci. Rep., 7:46074, 2017.
Kamal, M. T.; Hashem, M. A.; Al Mamun, M.; Hossain, M. M. \& Razzaque, M. A. Study of cattle fattening system in selected region of Bangladesh. SAARC J. Agric., 17(1):105-18, 2019.

Mehaisen, G. M.; Eshak, M. G.; Elkaiaty, A. M.; Atta, A. M.; Mashaly, M. M. \& Abass, A. O. Comprehensive growth performance, immune function, plasma biochemistry, gene expressions and cell death morphology responses to a daily corticosterone injection course in broiler chickens. PloS One, 12(2):e0172684, 2017.

Mostafa, M. M. E.; El-Faham, A. I. \& Ahmed, A. H. H. Effect of different sources of growth promoter supplementation in diet on performance, carcass traits and blood constituents of broiler chicks. Asian J. Anim. Vet. Adv., 11(2):106-13, 2016

Mottet, A. \& Tempio, G. Global poultry production: current state and future outlook and challenges. World Poult. Sci. J., 73(2):245-56, 2017.

Serratosa, J.; Blass, A.; Rigau, B.; Mongrell, B.; Rigau, T.; Tortadès, M.; Tolosa, E.; Aguilar, C.; Ribó, O. \& Balagué, J. Residues from veterinary medicinal products, growth promoters and performance enhancers in food-producing animals: a European Union perspective. Rev. Sci. Tech., 25(2):637-53, 2006.

Shini, S.; Huff, G. R.; Shini, A. \& Kaiser, P. Understanding stress-induced immunosuppression: exploration of cytokine and chemokine gene profiles in chicken peripheral leukocytes. Poult. Sci., 89(4):841-51, 2010.

Sultana, N.; Khan, M. Z. I.; Wares, M. A. \& Masum, M. A. Histomorphological study of the major lymphoid tissues in indigenous ducklings of Bangladesh. Bangladesh J. Vet. Med., 9(1):53-8, 2011.

Treesh, S. A.; Buker, A. O. \& Khair, N. S. Histological, histochemical and immunohistochemical studies on thymus of chicken. Int. Soc. Histol. Cytol., 1(11):103-11, 2014.

Vicuña, E. A.; Kuttappan, V. A.; Galarza-Seeber, R.; Latorre, J. D.; Faulkner, O. B.; Hargis, B. M.; Tellez, G. \& Bielke, L. R. Effect of dexamethasone in feed on intestinal permeability, differential white blood cell counts, and immune organs in broiler chicks. Poult. Sci., 94(9):2075-80, 2015.

Watteyn, A.; Wyns, H.; Plessers, E.; Russo, E.; De Baere, S.; De Backer, P. \& Croubels, S. Pharmacokinetics of dexamethasone after intravenous and intramuscular administration in broiler chickens. Vet. J., 195(2):216$20,2013$.

Yuan, Y.; Xu, C.; Peng, C.; Jin, Z.; Chen, W. \& Liu, L. Analytical methods for the detection of corticosteroids-residues in animal-derived foodstuffs. Crit. Rev. Anal. Chem., 38(4):227-41, 2008.

\section{Corresponding author: \\ Dr. Nasrin Sultana \\ Associate Professor \\ Dept. of Anatomy and Histology \\ Bangladesh Agricultural University \\ Mymensingh - BANGLADESH}

Email: nasrin.sultana@bau.edu.bd

Received: 25-12-2019

Accepted: 09-03-2020 